\title{
Flaxseed and Its Components in Treatment of Hyperlipidemia and Cardiovascular Disease
}

\author{
Kailash Prasad, MBBS (Hons), MD, PhD, DSc, FRCPC, FACC, FIACS, FICA ${ }^{1}$ Amal S. Khan, MBBS ${ }^{2}$ \\ Muhammad Shoker, BSc (Hons) ${ }^{1}$ \\ ${ }^{1}$ Department of Physiology (APP), College of Medicine, University of \\ Saskatchewan, Saskatoon, Saskatchewan, Canada \\ ${ }^{2}$ Community, Health and Epidemiology, College of Medicine, \\ University of Saskatchewan, Saskatoon, Saskatchewan, Canada \\ Address for correspondence Kailash Prasad, MBBS (Hons), MD, PhD, \\ DSc, Department of Physiology (APP), College of Medicine, University \\ of Saskatchewan, 107 Wiggins Road, Saskatoon, SK, S7N 5E5, Canada \\ (e-mail: k.prasad@usask.ca).
}

Int J Angiol 2020;29:216-222.

\begin{abstract}
Keywords

- flaxseed

- flax oil

- flaxlignan complex

- secoisolariciresinoldiglucoside

- serum lipids

- flaxseed dietary fibers

This paper describes the effects of flaxseed and its components (flax oil, secoisolariciresinoldiglucoside[SDG], flax lignan complex [FLC], and flax fibers] on serum lipids (total cholesterol [TC], low-density lipoprotein-cholesterol [LDL-C], high-density lipoprotein cholesterol [HDL-C], and triglycerides [TG]) in animals and humans. Ordinary flaxseed reduces TG, TC, LDL-C, and TC/HDL-C levels in a dose-dependent manner in animals. In humans, it reduces serum lipids in hypercholesterolemicpatients but has no effects in normocholesterolemicpatients. Flax oil has variable effects on serum lipids in normo- and hypercholesterolemic animals. Flax oil treatment, with a dosage containing greater than $25 \mathrm{~g} /$ day of $\alpha$-linolenic acid, reduces serum lipids in humans. Although FLC reduces serum lipids and raises serum HDL-C in animals, its effects on serum lipids in humans are small and variable. Flax fibers exert small effects on serum lipids in humans. Crop Development Centre (CDC)-flaxseed, which contains low concentrations of $\alpha$ linolenic acid, has significant lipid lowering effects in animals. Pure SDG has potent hypolipidemic effects and raises HDL-C. In conclusion, flaxseed and pure SDG have significant lipid-lowering effects in animals and humans, while other components of flaxseed have small and variable effects.
\end{abstract}

Hyperlipidemia is defined as elevated serum levels of total cholesterol, low-density lipoprotein-cholesterol (LDL-C), triglycerides, or all three. The causes of hyperlipidemia are genetic, environmental, and/or a combination of both. Hyperlipidemia is mostly acquired. Hyperlipidemia is second only to hypertension as a risk factor for cardiovascular diseases, including coronary artery disease, stroke, and peripheral vascular disease. ${ }^{1}$ High blood pressure and hypercholesterolemia are the two main causes of heart disease and stroke. ${ }^{2}$ Flaxseed and its components have been reported to suppress, regress, and slow the progression of hypercholesterolemic arthrosis. ${ }^{3-9}$ Coronary artery disease, peripheral artery disease, and stroke in the hypercholesterolemic individual may be due to hypercholesterolemia-induced atherosclerosis. Agents such as statins, bile acid sequestrants, nicotinic acid, fibric acid, and evolocumab have been used to lower serum lipids. ${ }^{10,11}$ Although there are no comparative studies demonstrating that alternative nutraceuticals, such as flaxseeds and its components, may be useful in lowering serum lipids, they seem to have potential for doing so. ${ }^{3-9}$ Tangentially, there are some reviews on the use of garlic $^{12}$ and artichoke leaf extracts ${ }^{13}$ in lowering serum lipids. The purpose of the present paper is to review the effects of flaxseeds and its components on serum/plasma lipids in normo- and hypercholesterolemic experimental models and human patients. This review will shed light on the therapeutic potential of flaxseeds and its components in hypercholesterolemia treatment. Therapeutic interventions with flaxseeds and its components may prevent, regress, and slow the progression of lipid-induced coronary artery disease, peripheral artery disease, and stroke by lowering serum lipid levels. published online April 14, 2020
Copyright $\odot 2020$ by Thieme Medical Publishers, Inc., 333 Seventh Avenue, New York, NY 10001, USA. Tel: +1(212) 760-0888.
DOI https://doi.org/ 10.1055/s-0040-1709129. ISSN 1061-1711. 


\section{Flaxseed and Its Components}

Flaxseed is the richest source of plant $\alpha$-linolenic acid (ALA) and lignans. ${ }^{14,15}$ Approximately 38 to $45 \%$ of its mass is oil, of which 51 to $55 \%$ is ALA and 15 to $18 \%$ is linoleic acid. ${ }^{16,17}$ Flax meal, which is devoid of oil, is approximately 55 to $68 \%$ the weight of flaxseed and contains approximately $16.4 \mathrm{mg} / \mathrm{g}$ of secoisolariciresinoldiglucoside (SDG). ${ }^{18}$ SDG is present mostly in the seed coat. ${ }^{19}$ SDG comprises between 0.6 to $6 \mathrm{~g}$ of $100-\mathrm{g}$ flaxseeds. ${ }^{6}$ Flax lignan complex isolated from flaxseeds is composed of, by weight, 34 to $38 \%$ SDG, 15 to $21 \%$ cinnamic acid glucoside, and 9.6 to $11 \%$ hydroxymethylglutaric acid. ${ }^{20}$ Flaxseed contains proteins $(10.5-31.0 \%$ by weight $)^{16}$ and fiber (25-28\% by weight), of which $25 \%$ is in the soluble form. ${ }^{21}$ Another variety of flaxseed, called CDCflaxseed, has similar oil and SDG content to ordinary flaxseed, but contains only 2 to $3 \%$ ALA by mass. ${ }^{18}$ This variety of flaxseed has different effects on serum lipids. ${ }^{18}$ We will discuss the effects of various components of flaxseed on serum lipids in the following subsequent sections.

\section{Flaxseed and Lipid Reduction}

\section{Animal Studies}

Animal models indicate that flaxseeds, when comprising $10 \%$ of the diet, do not affect serum lipid levels. However, at a dose of $20 \%$ of the diet, plasma levels of total cholesterol (TC), LDL-C, and triglycerides (TG) fell by 21,37 , and $23 \%$, respectively, in rats. ${ }^{22} \mathrm{At} 30 \%$ of the diet, flaxseed reduced TC, LDL-C, and TG by 33,67 , and 23, respectively. ${ }^{22}$ Flaxseed in doses of 27.8, 41.7, and $55.6 \%$ reduced TC and high-density lipoprotein cholesterol (HDL-C) but did not affect the plasma levels of TG in rats. ${ }^{23}$ Serum levels of TC were reduced in LDL receptor deficient (LDLr deficient) mice without alteration in TG by flaxseed. ${ }^{24}$ Lucas et $\mathrm{al}^{25}$ reported that flaxseed reduced the serum levels of TC, increased the levels of TG, and had no effect on serum HDL$C$ levels in the ovariectomized golden Syrian hamster animal model. ${ }^{26}$ However, Haliga et al ${ }^{26}$ showed that flaxseed reduced serum levels of TC by $24.9 \%$ and increased HDL-C by $91 \%$ in the streptozotocin-induced diabetic golden Syrian hamster animal model. Flaxseed has been shown to have no effect on serum TC and TG in normocholesterolemic rabbits. ${ }^{27}$ Prasad $^{3}$ reported that flaxseeds at an oral daily dose of $7.5 \mathrm{~g}$ per kg body weight for 8 weeks did not affect the serum levels of TC in normocholesterolemic rabbits, although it decreased them in hypercholesterolemic rabbits. The serum levels of TG were not affected in both normo- and hyper-cholesterolemic rabbits. Flaxseeds with very low ALA, CDC-flaxseeds, in the dose of $7.5 \mathrm{~g} / \mathrm{kg}$ body weight for 8 weeks, reduced the serum levels of TC, LDL-C, TC/HDL-C, and LDL-C/HDL-C by $31,32,34$, and $32 \%$, respectively, in hypercholesterolemic rabbits. ${ }^{18}$ The levels of TG and VLDL-C were also elevated in hypercholesterolemic rabbits. Serum HDL-C levels were unaltered both in normocholesterolemic and hypercholesterolemic rabbits. The above data suggest that, in normocholesterolemic rats, low doses of flaxseed do not alter the serum levels of TC, LDL-C, and TG, while high doses of flaxseed reduce serum levels of TC, LDL-C, and TG in a dose-dependent manner. Although flaxseed did not alter the serum levels of TC and TG in normocholesterolemic rabbits, it reduced the levels of TC in hypercholesterolemic rabbits and overectomized golden Syrian hamsters. In normocholesterolemic rabbits, CDC-flaxseed did not affect the serum levels of TC, LDL-C, VLDL-C, although it increased the levels of HDL-C.

\section{Human Studies}

Cunnaneet $\mathrm{al}^{28}$ reported a reduction of 9 and $18 \%$ in cholesterol and LDL-C, respectively, without changes in HDL-C, in healthy females fed 50-g flaxseeds per day for 4 weeks. Surprisingly, Jenkins et al ${ }^{29}$ reported a reduction of 5 and $8 \%$ in serum total cholesterol and LDL, in patients fed partially defatted flaxseeds for a 3-week period in a randomized crossover trial. Arjmandiet a ${ }^{30}$ reported a reduction of 6.9 , 14.7, and 7.4\% in TC, LDL-C, and lipoprotein A, respectively, in postmenopausal women fed 38-g flaxseed/day for 6 weeks. In a random double-blind, placebo-controlled trial in healthy menopausal women, $40 \mathrm{~g} /$ day flaxseed for 12 months reduced apoprotein (Apo) levels by $7.5 \%{ }^{31}$ Flaxseed reduced the serum levels of serum TC levels by $0.20 \pm 0.5 \mathrm{mmol} / \mathrm{L}(p=0.012)$ and HDL-C by $0.08 \pm 0.24 \mathrm{mmol} / \mathrm{L}(p=0.03)$. HDL and TG were not affected. Daily 30-g flaxseeds for 3 months reduced TC and LDL-C levels by 7 and 10\%, respectively, in 55 mild-to-moderate hypercholesterolemic native American postmenopausal women, while the levels of TG and HDL-C remained unaltered. ${ }^{33}$ Also, 30 -g milled flaxseed daily for 12 months reduced the plasma levels of TC and LDL-C in patients with peripheral artery disease by 11 to $15 \%$ at 1 month into the trial. ${ }^{34}$ The plasma levels of HDL-C did not change throughout. However, TG levels significantly increased at 12 months. Plasma TC and LDL-C levels were significantly attenuated by flaxseeds at 6 months compared with baseline. Bloedon et $\mathrm{al}^{35}$ reported that baked products containing flaxseed at a dose of $40 \mathrm{~g} / \mathrm{d}$ for 10 weeks, given to men and women with LDL-C between 130 and $200 \mathrm{mg} / \mathrm{dL}$, reduced the serum levels of LDL-C by $13 \%$ and lipoprotein A by $14 \%$ at 5 weeks. In men, flaxseed reduced the serum levels of HDL-C by 16 and $9 \%$ at 5 and 10 weeks, respectively. Demark-Wahnefriedet $\mathrm{al}^{36}$ reported that flaxseeds ( $30 \mathrm{~g} / \mathrm{d}$ for 30 days) significantly reduced serum cholesterol in prostate cancer patients on low fat diets. Lucas et $\mathrm{al}^{37}$ reported that ground flaxseeds ( $40 \mathrm{~g} / \mathrm{d}$ for 3 months) significantly reduced serum TC and non-HDL-C in postmenopausal women age below 65 years. The decreases in serum LDL-C and TG were 4.7 and $12.8 \%$, respectively, but neither decrease was significant. In a randomized controlled clinical trial, in hyperlipidemic individuals, 30-g raw flaxseed powder for 40 days reduced the serum levels of TC, LDL-C, and TG significantly (TC [226.05 vs. $214.53 \mathrm{mg} / \mathrm{dL}]$, LDL-C $[133.8 \pm 7.76$ vs. $130.7 \pm 56-$ $\mathrm{mg} / \mathrm{dL}]$, and TG $[226.05 \pm 18.7$ vs. $176.6 \pm 11.1 \mathrm{mg} / \mathrm{dL}]) .{ }^{38} \mathrm{The}$ levels of HDL-C remained unaltered. In the control group, the serum levels of TC, LDL-C, and TG increased significantly. The HDL-C levels in the control group remained unaltered. Stuglin and Prasad ${ }^{39}$ reported that consumption of three muffins containing 32.7-g flaxseeds daily for 4 weeks in healthy young adults did not alter the serum levels of TC, LDL-C, HDL-C, and very low-density lipoproteins (VLDL-C). However, the serum levels of TG were significantly elevated. 
Machado et $\mathrm{al}^{40}$ used $28 \mathrm{~g} / \mathrm{d}$ of brown flaxseeds and golden flaxseeds in 75 overweight boys and girls for 11 weeks (Monday-Friday/week) and observed no significant differences in lipid profiles. There were no significant changes in serum TC, LDL-C, HDL-C, TC/HDL-C, and LDL-C/HDL-C.

The above data suggest that flaxseed, in general, reduces the serum levels of TC, LDL-C, and TG in hypercholesterolemicpatients. Flaxseed has nonsignificant effects on serum lipids in normocholesterolemicpatients.

\section{Flaxseed Oil and Lipid Reduction}

\section{Animal Studies}

Ranhotraet $\mathrm{al}^{41}$ showed that consumption of flaxseed oil for 6 weeks did not lower serum TC in hypercholesterolemic rats. However, the combination of defatted flaxseeds meal and flaxseeds oil significantly reduced serum cholesterol levels in rats. ${ }^{41}$ Flaxseed oil ( $1 \mathrm{~g} / \mathrm{kg}$ body weight for 60 days) significantly reduced the plasma level of TC and TG in high fat diet-fed white rats. However, flaxseed oil had no effect on TC and TG levels in normal diet-fed rats. ${ }^{42}$ Flaxseed oil at $5 \%$ of the diet for 8 weeks did not affect the serum levels of TC, LDLC, HDL-C, TG, and TC/HDL-C in hypercholesterolemic rabbits and normocholesterolemic rabbits. ${ }^{4}$ Flaxseed oil did not prevent the rise in TC in ovariectomized Syrian hamsters although flaxseed did prevent this rise. ${ }^{43}$ Nounou et $\mathrm{al}^{44}$ showed that myocardial ischemia in rats increases the serum levels of TC and TG, decreases the serum level of LDL-C, and has no effect on HDL-C. In their study, they showed that flaxseed oil $(0.4 \mathrm{~g} / \mathrm{kg}$ daily for 6 weeks) reduced the serum levels of TG, TC, and LDL-C, but had no effect on HDL-C in rats with myocardial ischemia. Flaxseed, along with exercise in rats with myocardial ischemia, did not affect the serum levels of TG, TC, and LDL-C but increased the serum level of HDL-C. The data suggest that flaxseed and exercise is effective in raising HDL-C in myocardial ischemia. Taken together, the above data show that the effects of flaxseed oil on serum lipids was variable in hypercholesterolemic and normocholesterolemic animals.

\section{Human Studies}

Flax oil administered to firefighters in doses of 1.2, 2.4, and $3.6 \mathrm{~g} / \mathrm{d}$ for 12 weeks did not produce any significant changes in the serum levels of TC, HDL-C, and TG. ${ }^{45}$ Flax oil administered to 56 noncoronary artery disease individuals, in doses containing 3-g ALA for 26 weeks, significantly reduced TC levels $(4.95 \pm 0.99$ vs. $5.43 \pm 0.00 \mathrm{mmol} / \mathrm{dL}){ }^{46}$ However, these investigators did not find any significant change in the serum levels of HDL-C, LDL-C, and TG. ALA did not affect LDL particle size. There was no effect on the concentrations of large, less atherogenic LDL-1 and LDL-2 subfractions. Kaulet $\mathrm{al}^{47}$ reported that oral administration of flax oil ( $1 \mathrm{~g} / \mathrm{d}$ for 3 months) to healthy patients did not significantly alter serum levels of TC, HDL-C, LDL-C, and TG. A flax oil diet containing $28.8 \%$ of its energy from fat did not significantly alter serum TG, TC, HDL-C, LDL-C, Apo-A1, and Apo-B levels in healthy adults. ${ }^{48}$ Kestin et al $^{49}$ reported that there was no effect of ALA ( $9.2 \mathrm{~g} / \mathrm{d}$ for 6 weeks) on plasma
LDL-C, TG, and VLDL-C in 33 normotensive and mildly hypercholesterolemic men. Consumption of flax oil containing 8.1-g ALA/d for 12 weeks by 40 dyslipidemicpatients (aged, 38-71 years) did not alter the serum levels of TC, TG, HDL-C, and LDL-C. ${ }^{50}$ Flaxseed oil $(15 \mathrm{~g} / \mathrm{d})$, containing $8-\mathrm{g}$ ALA, given to healthy patients for 12 weeks reduced the serum levels of HDL-C $(42.7 \pm 10.4 \mathrm{vs} .42 .0 \pm 10.2 \mathrm{mg} / \mathrm{dL}$, $p<0.005)$ but had no effect on TC, TG, and LDL-C. ${ }^{51}$ Singer et $\mathrm{al}^{52}$ reported that flaxseed oil $(60 \mathrm{~mL} / \mathrm{d}$ for 2 weeks $)$ given to 14 mild essential hypertensive patients significantly decreased the serum levels of TC, LDL-C, TG, and LDL-C/HDL-C ratios. Flaxseed oil $(30 \mathrm{~mL} / \mathrm{d}$ for 4 weeks) given to healthy volunteers decreased serum levels of TG and apolipoprotein-B significantly, at $1.23 \pm 0.64$ vs. $1.03 \pm 0.44 \mathrm{mmol} / \mathrm{L}$ and $1.06 \pm 0.24$ vs. $1.00 \pm 0.25 \mathrm{~g} / \mathrm{L}$, respectively. ${ }^{53}$ It also significantly decreased the ratio of TC/HDL-C ( $4.15 \pm 1.44$ vs. $3.85 \pm 1.19)$. In a double-blind controlled trial with 34 hemodialysis patients, Mirfatahi et $\mathrm{al}^{54}$ showed that flaxseed oil ( $6 \mathrm{~g} / \mathrm{d}$ for 8 weeks) significantly reduced serum TG levels by $23 \%$. There were no significant changes in the serum levels of TC, LDL-C, HDL-C, and lipoprotein(A).

Akrami et $\mathrm{al}^{55}$ reported that flax oil $(25 \mathrm{~mL} / \mathrm{d})$ given to patients with metabolic syndrome for 7 weeks reduced the serum levels of TC, TG, LDL-C, and HDL-C by $18.23 \pm 25.45 \mathrm{mg} / \mathrm{L}$ $(p<0.001), 52.46 \pm 74.32 \mathrm{mg} / \mathrm{dL}(p=0.001), 7.19 \pm 17.47 \mathrm{mg}$ $(p=0.46)$ and $-1.38 \pm 3.34 \mathrm{mg} / \mathrm{dL}(p=0.45)$, respectively. Consumption of $10 \mathrm{~mL}$ of flaxseed oil (6-g ALA/day) for 14 days in young women did not significantly alter the concentration of TC $(4.44 \pm 0.73$ vs. $4.49 \pm 0.88 \mathrm{mmol} / \mathrm{L})$, LDL-C $(2.55 \pm 0.68$ vs. $2.63 \pm 0.73 \mathrm{mmol} / \mathrm{L}), \quad H D L-C(1.50 \pm 0.30$ vs. $1.50 \pm 0.32$ $\mathrm{mmol} / \mathrm{L})$, and TG $(1.03 \pm 0.36$ vs. $0.96 \pm 0.35 \mathrm{mmol} / \mathrm{L}) \mathrm{com}-$ pared with baseline. ${ }^{56}$ In another study, the effect of $10-\mathrm{g}$ flax oil containing 5.49-g ALA, and 10-g corn oil containing 0.09 -g ALA, consumed daily for 12 weeks in 15 patients was observed. Flax oil significantly reduced CETP levels and to a greater degree than corn oil. Also, the serum levels of TC, LDL-C, HDL-C, and non-HDL-C, Apo-A1, and Apo-B levels were significantly lower with flax oil than with corn oil. The levels of TG were not affected with either flax oil or corn oil. The data suggest that flax oil certainly reduces the levels of TC, LDL-C, HDL-C, non-HDL-C, Apo-A, and Apo-B. ${ }^{57}$

The data suggest that the effect of flaxseed oil is highly variable on the serum lipids in the normocholesterolemic and hypercholesterolemicpatients. It appears that high doses (>25-g ALA) reduce the serum levels of TC, LDL-C, HDL-C, TG, Apo-A1, and Apo-B.

\section{SecoisolariciresinolDiglucoside(SDG) and Lipid Reduction}

\section{Animal Studies}

SDG in the oral dose of $15 \mathrm{mg} / \mathrm{kg}$ body weight daily for 8 weeks did not alter the serum levels of TG, TC, LDL-C, HDL-C, LDL-C/HDL-C, and TC/HDL-C in normocholesterolemic rabbits. $^{6}$ However, SDG in the above dose reduced the serum levels of TC by $33 \%$, LDL-C by $35 \%$, TC/HDL-C by $64 \%$, and LDL-C/HDL-C by $64 \%{ }^{6}$ It also increased the levels of HDL-C by 
$140 \%$ initially but did not alter the levels TG in hypercholesterolemic rabbits. ${ }^{6}$ SDG at a dose of $1 \%$ in the diet reduced the serum levels of TG by $38 \%$ and TC by $15 \%$ in high fat fed mice. ${ }^{58}$ Consumption of SDG (oral $20 \mathrm{mg} / \mathrm{kg}$ daily) for 8 weeks reduced the serum levels of TC by $33 \%$, TG by $39 \%$, and LDL-C by $45 \%$, and raised the levels of HDL-C by $22 \%$ in hypercholesterolemic rats. ${ }^{59}$ Felmlee et $\mathrm{al}^{60}$ reported that oral administration of oral 0,3 , or $6 \mathrm{mg} S \mathrm{SDG} / \mathrm{kg}$ body weight daily, or oral $0,1.6$, or $3.2 \mathrm{mg} / \mathrm{kg}$ body weight daily for 4 weeks of an aglycone called secoisolaricinol, produced dose-dependent decreases in the serum levels of TC and LDL-C in hyperlipidemic rats. Zanwar et $\mathrm{al}^{61}$ reported that $20 \mathrm{mg} / \mathrm{kg}$ body weight of SDG given orally significantly reduced the serum levels of TG, TC, and VLDL-C, while nonsignificantly increasing the serum levels of HDL-C in poloxamer-407-induced hyperlipidemic mice.

The data suggest that pure SDG markedly reduces the serum levels of TC, LDL-C, TC/HDL-C, and LDL-C/HDL-C, and raises the levels of HDL-C in hypercholesterolemic animals. However, SDG does not alter the serum levels TC, LDL-C, TG, HDL-C, TC/HDL-C, and LDL-C/HDL-C in normocholesterolemic rabbits. To our knowledge, the effects of pure SDG on serum lipids are yet to be tested.

\section{Flax Lignan Complex and Lipid Reduction}

\section{Animal Studies}

Prasad $^{5}$ reported that FLC in the oral daily dose of $40 \mathrm{mg} / \mathrm{kg}$ body weight for 2 months did not alter the levels of serum TG, TC, and LDL-C, but increased the levels of HDL-C in normocholesterolemic rabbits. In hypercholesterolemic rabbits, FLC in the dose of $40 \mathrm{mg} / \mathrm{kg}$ body weight daily for 8 weeks decreased the serum levels of TC, LDL-C, and TC/HDL-C, respectively, by 20,14 , and $34 \%$, while raising HDL-C levels by $30 \%$ and having no effect on serum levels of TG. The data suggest that FLC is effective in lowering serum lipids in hyperlipidemic animals but not in normocholesterolemic animals.

\section{Human Studies}

In a randomized, double-blind, placebo-controlled study, administration of $300 \mathrm{mg} / \mathrm{d}$ or $600 \mathrm{mg} / \mathrm{d}$ of dietary SDG, taken from flaxseed extract, to hypercholesterolemicpatients for 8 weeks significantly reduced the plasma levels TC and LDL-C. ${ }^{62}$ They showed that $300 \mathrm{mg}$ of FLC/day reduced plasma TC and LDL-C levels by 15.47 and $17.04 \%$, respectively, while the dose of $600 \mathrm{mg} / \mathrm{d}$ reduced them by 22.0 and $24.38 \%$, respectively. HDL-C at 8 weeks decreased significantly in the $600 \mathrm{mg} / \mathrm{d}$ SDG treatment group, compared with placebo. In the $600 \mathrm{mg}$ group, the ratio of TC/HDL-C decreased significantly but there was no significant difference between the groups. TG levels in the $600 \mathrm{mg}$ group decreased significantly only within the groups. ${ }^{62}$ In a randomized, double-blind, placebo-controlled crossover study, Hallund et $\mathrm{al}^{63}$ investigated the effect of FLC on plasma lipids in healthy postmenopausal women with the dosage of $500 \mathrm{mg} / \mathrm{d}$ SDG for 6 weeks. They found that FLC did not affect the plasma levels of TC, LDL-C, HDL-C, and TG. In another randomized, double-blind, placebo-controlled study, Cornish et al $^{64}$ reported that $550 \mathrm{mg} / \mathrm{d}$ FLC for 6 months did not alter the serum levels of TC, LDL-C, and TG, but decreased the levels of HDL-C. In another randomized double-blind placebocontrolled trial, where flaxseed lignan extract equivalent to either 20- or 100-mg SDG daily for 12 weeks was given, the serum levels of TC and LDL-C decreased by 6.2 and $8.4 \%$, respectively, in the $100-\mathrm{mg}$ group. ${ }^{65}$ The ratio of LDL-C/HDL-C decreased significantly in this group as well. There were neither significant changes in the levels of TG and HDL-C within nor between groups. The 20-mg SDG dose did not affect the levels of TC, LDL-C, HDL-C, TG, and LDL-C/HDL-C. In a double-blind, randomized crossover, placebo-controlled study in postmenopausal women, Barreet $\mathrm{al}^{66}$ reported that none of the blood lipids (i.e., TC, HDL-C, LDL-C, TG, and TC/HDL-C) were altered by FLC with a dose equivalent to $600-\mathrm{mg}$ SDG/d for 3 months. Pan et $\mathrm{al}^{67}$ reported that, in a randomized, double blind, placebocontrolled, crossover trial of 73 diabetics with mild hypercholesterolemia, FLC equivalent to 360-mg SDG/d for 12 weeks did not significantly affect the serum levels of TC, LDL-C, TG, lipoprotein (A), apo-A, and apo-B.

The data suggest that the effects of FLC on serum lipids are variable irrespective of normocholesterolemia and hypercholesterolemia.

\section{Flaxseed Dietary Fibers and Lipid Reduction}

In a double-blind randomized crossover trial of 17 young patients, Kristensenet $\mathrm{al}^{68}$ investigated the effects of flax fiber drink and flax fiber bread. Both contained 5.2-g flaxseed dietary fiber and were given three times per day for 7 days. They found that flax fiber drink reduced the serum levels of TC by $12 \%$ and LDL-C by $15 \%$ ( $p=0.001$ ), while flax fiber bread reduced the serum levels of TC by $7 \%$ and LDL-C by 7 and $9 \%$, respectively. $(p=0.05)$. Thakur et $\mathrm{al}^{69}$ reported that flaxseed gum incorporated bread, containing 5-g flaxseed soluble fiber, given to 60 type-2 diabetic patients for 3 months, reduced the serum levels of TC from $182 \pm 11 \mathrm{mg} / \mathrm{dL}$ to $163 \pm 9 \mathrm{mg} / \mathrm{dL}$ $(p<0.03)$, and LDL-C from $110.8 \pm 8$ to $92 \pm 9 \mathrm{mg} / \mathrm{dL}$ $(p=0.02)$. In a prospective cohort study of participants, who are free of cardiovascular disease for approximately 6.5 years, consumption of flax-fiber-enriched drinks $(10 \mathrm{~g} / \mathrm{d})$ or higher reduced serum cholesterol. ${ }^{70}$ Taken together, the data suggest that flaxseed fiber has mild hypocholesterolemic effects.

\section{Perspectives}

CDC-flaxseed, which contains low-ALA content, reduced the serum levels of TC and LDL-C more than ordinary flaxseed, while raising serum TG levels in animal models. Both ordinary flaxseed and CDC-flaxseed had no effects on the serum levels of HDL-C. The greater reduction of TC and LDL-C and elevation of serum TG levels with CDC-flaxseed could be due to its lower levels of ALA because it is known to decrease the serum levels of TG. ${ }^{49}$ Meanwhile, SDG appears to be very potent in lowering serum TC, LDL-C, TC/LDL-C, and LDL-C/HDL-C, in addition to raising HDL-C in rabbits. However, SDG has not been tested in humans because of its nonavailability in large amounts. This could prove to be a potent agent for lowering lipids and elevating good 
cholesterol. The effects of flaxseed and its constituents are variable, which may be due to variable doses and species variations. The small effects of flaxseed and its constituents may be due to small doses and frequency of administration. Large doses at frequent intervals may have significant effects on serum lipids. Information gaps in the literature can be addressed. First, studies should be conducted in experimental animals with various doses of flaxseed, flax oil, SDG, FLC, and flaxseed fiber to determine optimal doses for improving serum lipid levels. With this approach, optimal dosage of flaxseed and its constituents can be determined. Clinical studies should then be conducted.

The present data suggest that flaxseed oil, FLC, and flaxseed fibers may not serve as therapeutic agents for lowering serum TC, TG, LDL-C, TC/HDL-c, and LDL-C/HDL-c, not even for elevating serum levels of HDL-C. They may be used as adjunctive therapeutic agents for treatment of hyperlipidemia. Flaxseed and SDG may serve as therapeutic agents for hyperlipidemia treatment. To date, the effects of SDG have not been tested in patients with normocholesterolemia nor hypercholesterolemia. SDG and FLC may be very useful in elevating serum levels of HDL-C. Flaxseed and its constituents may serve as preventive measures against hypercholesterolemia and familial hypercholesterolemia.

\section{Conclusion}

Flaxseed reduced the serum levels of TC, LDL-C, and TG in a dose-dependent manner in rats, hypercholesterolemic rabbits, and ovariectomized golden Syrian hamsters. CDC-flaxseed markedly reduced serum TC, LDL-C, TC/HDL-C, and LDL-C/HDL-C in rabbits. Flaxseed reduced the serum levels of TC, LDL-C, and TG in hypercholesterolemic subjects but had no effects in normocholesterolemic subjects. Flaxseed oil has variable and small effects in animals but reduces the serum levels of TC, LDL-C, HDL-C, TG, Apo-A1, and Apo-B in humans. Pure SDG markedly and significantly reduces the serum levels of TC, TG, LDL-C, TC/HDL-C, and LDL-C/HDL-C in hypercholesterolemic rabbits, rats, and mice. FLC reduced the serum levels of TC, TG, and LDL-C, and increased the levels of HDL-C, in hypercholesterolemic rabbits. It did not, however, affect serum lipids in normocholesterolemic rabbits, with the exception of increasing HDL-C. The effects of FLC on serum lipids were very variable and small in subjects with or without hypercholesterolemia. Flaxseed fiber had mild effects on serum lipids in humans. In conclusion, flaxseed and pure SDG have significant lipid-lowering effects in animals and humans, while other components of flaxseed have variable and small effects.

\section{Conflicts of Interest}

The authors have no conflicts of interest to declare.

\section{References}

1 Centers for Disease Control and Prevention. National ambulatory medical care survey: 2009 summary tables. Available at: https:// www.cdc.gov/nchs/data/ahcd/namcs_summary/2009_namcs_web_ tables.pdf. Accessed February 19, 2020
2 Centers for Disease Control and Prevention. Vital signs: high blood pressure and cholesterol. Available at: https://www.cdc.gov/dhdsp/vital_signs_hbpc.htm. Accessed February 19, 2020

3 Prasad K. Dietary flax seed in prevention of hypercholesterolemic atherosclerosis. Atherosclerosis 1997;132(01):69-76

4 Lee P, Prasad K. Effects of flaxseed oil on serum lipids and atherosclerosis in hypercholesterolemic rabbits. J CardiovascPharmacol Ther 2003;8(03):227-235

5 Prasad K. Hypocholesterolemic and antiatherosclerotic effect of flax lignan complex isolated from flaxseed. Atherosclerosis 2005; 179(02):269-275

6 Prasad K. Reduction of serum cholesterol and hypercholesterolemic atherosclerosis in rabbits by secoisolariciresinoldiglucoside isolated from flaxseed. Circulation 1999;99(10):1355-1362

7 Prasad K. A study on regression of hypercholesterolemic atherosclerosis in rabbits by flax lignan complex. J Cardiovasc PharmacolTher 2007;12(04):304-313

8 Prasad K. Regression of hypercholesterolemic atherosclerosis in rabbits by secoisolariciresinoldiglucoside isolated from flaxseed. Atherosclerosis 2008;197(01):34-42

9 Prasad K. Flax lignan complex slows down the progression of atherosclerosis in hyperlipidemic rabbits. J Cardiovasc PharmacolTher 2009;14(01):38-48

10 Whayne TF Jr. Defining the Role of PCSK9 Inhibitors in the Treatment of Hyperlipidemia. Am J Cardiovasc Drugs 2016;16 (02):83-92

11 Safeer RS, Lacivita CL. Choosing drug therapy for patients with hyperlipidemia. Am Fam Physician 2000;61(11):3371-3382

12 Stevinson C, Pittler MH, Ernst E. Garlic for treating hypercholesterolemia. A meta-analysis of randomized clinical trials. Ann Intern Med 2000;133(06):420-429

13 Wider B, Pittler MH, Thompson-Coon J, Ernst E. WITHDRAWN: Artichoke leaf extract for treating hypercholesterolaemia. Cochrane Database Syst Rev 2016;(05):CD003335

14 Kelley DS, Branch LB, Love JE, Taylor PC, Rivera YM, Iacono JM. Dietary alpha-linolenic acid and immunocompetence in humans. Am J Clin Nutr 1991;53(01):40-46

15 Thompson LU, Robb P, Serraino M, Cheung F. Mammalian lignan production from various foods. Nutr Cancer 1991;16(01):43-52

16 Oomah BD, Mazza G. Flaxseed proteins: a review. Food Chem 1993;48:109-114

17 Hettiarachchy NS, Hareland GA, Ostenson A, Bladner-Shank G. Chemical composition of 11 flaxseed varieties grown in North Dakota. Proc Flax Institute. 1990;53:36-50

18 Prasad K, Mantha SV, Muir AD, Westcott ND. Reduction of hypercholesterolemic atherosclerosis by CDC-flaxseed with very low alpha-linolenic acid. Atherosclerosis 1998;136(02):367-375

19 Hano C, Martin I, Fliniaux O, et al. Pinoresinol-lariciresinolreductase gene expression and secoisolariciresinoldiglucoside accumulation in developing flax (Linum usitatissimum) seeds. Planta 2006;224(06):1291-1301

20 Westcott ND, Paton D. Complex containing lignan, phenolic and aliphatic substances from flax and process for preparing. US Patent 6, 334, 557. December 28, 2000

21 Bernacchia R, Preti R, Vinci G. Chemical composition and health benefits of flaxseed. Austin J Nutr Food Sci 2014;2:1045

22 Ratnayake WM, Behrens WA, Fischer PW, L'Abbé MR, Mongeau R, Beare-Rogers JL. Chemical and nutritional studies of flaxseed (variety Linott) in rats. J Nutr Biochem 1992;3(05):232-240

23 Kritchevsky D, Tepper SA, Klurfeld DM. Influence of flaxseed on serum and liver lipids in rats. J Nutr Biochem 1991;2:133-134

24 Dupasquier CM, Dibrov E, Kneesh AL, et al. Dietary flaxseed inhibits atherosclerosis in the LDL receptor-deficient mouse in part through antiproliferative and anti-inflammatory actions. Am J Physiol Heart Circ Physiol 2007;293(04):H2394-H2402

25 Lucas EA, Lightfoot SA, Hammond LJ, et al. Flaxseed reduces plasma cholesterol and atherosclerotic lesion formation in ovariectomized Golden Syrian hamsters. Atherosclerosis 2004;173(02):223-229 
26 Haliga R, Mocanu V, Oboroceanu T, Stitt PA, Luca VC. The effects of dietary flaxseed supplementation on lipid metabolism in streptozotocin-induced diabetic hamsters. Rev Med Chir Soc Med Nat Iasi 2007;111(02):472-476

27 Dupasquier CM, Weber AM, Ander BP, et al. Effects of dietary flaxseed on vascular contractile function and atherosclerosis during prolonged hypercholesterolemia in rabbits. Am J Physiol Heart Circ Physiol 2006;291(06):H2987-H2996

28 Cunnane SC, Ganguli S, Menard C, et al. High alpha-linolenic acid flaxseed (Linum usitatissimum): some nutritional properties in humans. Br J Nutr 1993;69(02):443-453

29 Jenkins DJ, Kendall CW, Vidgen E, et al. Health aspects of partially defatted flaxseed, including effects on serum lipids, oxidative measures, and ex vivo androgen and progestin activity: a controlled crossover trial. Am J Clin Nutr 1999;69(03):395-402

30 Arjmandi BH, Khan DA, Juma S, et al. Whole flaxseed consumption lowers serum LDL-cholesterol and lipoprotein (a) concentrations in postmenopausal women. Nutr Res 1998;18(07):1203-1214

31 Dodin S, Cunnane SC, Mâsse B, et al. Flaxseed on cardiovascular disease markers in healthy menopausal women: a randomized, double-blind, placebo-controlled trial. Nutrition 2008;24(01): 23-30

32 Dodin S, Lemay A, Jacques H, Légaré F, Forest JC, Mâsse B. The effects of flaxseed dietary supplement on lipid profile, bone mineral density, and symptoms in menopausal women: a randomized, double-blind, wheat germ placebo-controlled clinical trial. J Clin Endocrinol Metab 2005;90(03):1390-1397

33 Patade A, Devareddy L, Lucas EA, Korlagunta K, Daggy BP, Arjmandi BH. Flaxseed reduces total and LDL cholesterol concentrations in Native American postmenopausal women. J Womens Health (Larchmt) 2008;17(03):355-366

34 Edel AL, Rodriguez-Leyva D, Maddaford TG, et al. Dietary flaxseed independently lowers circulating cholesterol and lowers it beyond the effects of cholesterol-lowering medications alone in patients with peripheral artery disease. J Nutr 2015;145(04): 749-757

35 Bloedon LT, Balikai S, Chittams J, et al. Flaxseed and cardiovascular risk factors: results from a double blind, randomized, controlled clinical trial. J Am Coll Nutr 2008;27(01):65-74

36 Demark-Wahnefried W, Polascik TJ, George SL, et al. Flaxseed supplementation (not dietary fat restriction) reduces prostate cancer proliferation rates in men presurgery. Cancer Epidemiol Biomarkers Prev 2008;17(12):3577-3587

37 Lucas EA, Wild RD, Hammond LJ, et al. Flaxseed improves lipid profile without altering biomarkers of bone metabolism in postmenopausal women. J Clin Endocrinol Metab 2002;87(04): 1527-1532

38 Torkan M, Entezari MH, Siavash M. Effect of flaxseed on blood lipid level in hyperlipidemic patients. Rev Recent Clin Trials 2015; 10(01):61-67

39 Stuglin C, Prasad K. Effect of flaxseed consumption on blood pressure, serum lipids, hemopoietic system and liver and kidney enzymes in healthy humans. J Cardiovasc Pharmacol Ther 2005; 10(01):23-27

40 Machado AM, de Paula H, Cardoso LD, Costa NM. Effects of brown and golden flaxseed on the lipid profile, glycemia, inflammatory biomarkers, blood pressure and body composition in overweight adolescents. Nutrition 2015;31(01):90-96

41 Ranhotra GS, Gelroth JA, Glaser BK, Potnis PS. Lipidemic responses in rats fed flaxseed oil and meal. Cereal Chem 1993;70:364-366

42 Vijaimohan K, Jainu M, Sabitha KE, Subramaniyam S, Anandhan C, Shyamala Devi CS. Beneficial effects of alpha linolenic acid rich flaxseed oil on growth performance and hepatic cholesterol metabolism in high fat diet fed rats. Life Sci 2006;79(05):448-454

43 Lucas EA, Mahajan SS, Soung Y, Lightfoot SA, Smith BJ, Arjmandi $\mathrm{BH}$. Flaxseed but not flaxseed oil prevented the rise in serum cholesterol due to ovariectomy in the Golden Syrian hamsters. J Med Food 2011;14(03):261-267
44 Nounou HA, Deif MM, Shalaby MA. Effect of flaxseed supplementation and exercise training on lipid profile, oxidative stress and inflammation in rats with myocardial ischemia. Lipids Health Dis 2012;11:129

45 Barceló-Coblijn G, Murphy EJ, Othman R, Moghadasian MH, Kashour T, Friel JK. Flaxseed oil and fish-oil capsule consumption alters human red blood cell $n-3$ fatty acid composition: a multiple-dosing trial comparing 2 sources of n-3 fatty acid. Am J Clin Nutr 2008;88(03):801-809

46 Harper CR, Edwards MC, Jacobson TA. Flaxseed oil supplementation does not affect plasma lipoprotein concentration or particle size in human subjects. J Nutr 2006;136(11):2844-2848

$47 \mathrm{Kaul} \mathrm{N,} \mathrm{Kreml} \mathrm{R,} \mathrm{Austria} \mathrm{JA,} \mathrm{et} \mathrm{al.} \mathrm{A} \mathrm{comparison} \mathrm{of} \mathrm{fish} \mathrm{oil,} \mathrm{flaxseed}$ oil and hempseed oil supplementation on selected parameters of cardiovascular health in healthy volunteers. J Am Coll Nutr 2008; 27(01):51-58

48 Kelley DS, Nelson GJ, Love JE, et al. Dietary $\alpha$-linolenic acid alters tissue fatty acid composition, but not blood lipids, lipoproteins or coagulation status in humans. Lipids 1993;28(06):533-537

49 Kestin M, Clifton P, Belling GB, Nestel PJ. n-3 fatty acids of marine origin lower systolic blood pressure and triglycerides but raise LDL cholesterol compared with n-3 and n- 6 fatty acids from plants. Am J Clin Nutr 1990;51(06):1028-1034

50 Paschos GK, Zampelas A, Panagiotakos DB, et al. Effects of flaxseed oil supplementation on plasma adiponectin levels in dyslipidemic men. Eur J Nutr 2007;46(06):315-320

51 Rallidis LS, Paschos G, Liakos GK, Velissaridou AH, Anastasiadis G, Zampelas A. Dietary $\alpha$-linolenic acid decreases $C$-reactive protein, serum amyloid $A$ and interleukin- 6 in dyslipidaemic patients. Atherosclerosis 2003;167(02):237-242

52 Singer P, Jaeger W, Berger I, et al. Effects of dietary oleic, linoleic and alpha-linolenic acids on blood pressure, serum lipids, lipoproteins and the formation of eicosanoid precursors in patients with mild essential hypertension. J Hum Hypertens 1990;4(03): 227-233

53 Schwab US, Callaway JC, Erkkilä AT, Gynther J, Uusitupa MI, Järvinen $T$. Effects of hempseed and flaxseed oils on the profile of serum lipids, serum total and lipoprotein lipid concentrations and haemostatic factors. Eur J Nutr 2006;45(08):470-477

54 Mirfatahi M, Tabibi H, Nasrollahi A, Hedayati M. Effects of Flaxseed Oil on Serum Lipids and Lipoproteins in Hemodialysis Patients: a Randomized Controlled Trial. Iran J Kidney Dis 2016; 10(06):405-412

55 Akrami A, Nikaein F, Babajafari S, Faghih S, Yarmohammadi H. Comparison of the effects of flaxseed oil and sunflower seed oil consumption on serum glucose, lipid profile, blood pressure, and lipid peroxidation in patients with metabolic syndrome. J Clin Lipidol 2018;12(01):70-77

56 Hodson L, Crowe FL, McLachlan KJ, Skeaff CM. Effect of supplementation with flaxseed oil and different doses of fish oil for 2 weeks on plasma phosphatidylcholine fatty acids in young women. Eur J Clin Nutr 2018;72(06):832-840

57 Kawakami Y, Yamanaka-Okumura H, Naniwa-Kuroki Y, Sakuma $M$, Taketani Y, Takeda E. Flaxseed oil intake reduces serum small dense low-density lipoprotein concentrations in Japanese men: a randomized, double blind, crossover study. Nutr J 2015;14:39

58 Fukumitsu S, Aida K, Ueno N, Ozawa S, Takahashi Y, Kobori M. Flaxseed lignan attenuates high-fat diet-induced fat accumulation and induces adiponectin expression in mice. Br J Nutr 2008; 100(03):669-676

59 Penumathsa SV, Koneru S, Zhan L, et al. Secoisolariciresinoldiglucoside induces neovascularization-mediated cardioprotection against ischemia-reperfusion injury in hypercholesterolemic myocardium. J Mol Cell Cardiol 2008;44(01):170-179

60 Felmlee MA, Woo G, Simko E, Krol ES, Muir AD, Alcorn J. Effects of the flaxseed lignanssecoisolariciresinoldiglucoside and its aglycone on serum and hepatic lipids in hyperlipidaemic rats. Br J Nutr 2009;102(03):361-369 
61 Zanwar AA, Hegde MV, Rojatkar SR, Sonawane KB, Rajamohanan PR, Bodhankar SL. Isolation, characterization and antihyperlipidemic activity of secoisolariciresinoldiglucoside in poloxamer407-induced experimental hyperlipidemia. Pharm Biol 2014;52 (09):1094-1103

62 Zhang W, Wang X, Liu Y, et al. Dietary flaxseed lignan extract lowers plasma cholesterol and glucose concentrations in hypercholesterolaemic subjects. Br J Nutr 2008;99(06):1301-1309

63 Hallund J, Tetens I, Bügel S, Tholstrup T, Bruun JM. The effect of a lignan complex isolated from flaxseed on inflammation markers in healthy postmenopausal women. Nutr Metab Cardiovasc Dis 2008;18(07):497-502

64 Cornish SM, Chilibeck PD, Paus-Jennsen L, et al. A randomized controlled trial of the effects of flaxseed lignan complex on metabolic syndrome composite score and bone mineral in older adults. Appl Physiol Nutr Metab 2009;34(02):89-98

65 Fukumitsu S, Aida K, Shimizu H, Toyoda K. Flaxseed lignan lowers blood cholesterol and decreases liver disease risk factors in moderately hypercholesterolemic men. Nutr Res 2010;30(07): 441-446

66 Barre DE, Mizier-Barre KA, Stelmach E, et al. Flaxseed lignan complex administration in older human type 2 diabetics manages central obesity and prothrombosis-an invitation to further investigation into polypharmacy reduction. J Nutr Metab 2012;2012:585170

67 Pan A, Sun J, Chen Y, et al. Effects of a flaxseed-derived lignan supplement in type 2 diabetic patients: a randomized, doubleblind, cross-over trial. PLoS One 2007;2(11):e1148

68 Kristensen M, Jensen MG, Aarestrup J, et al. Flaxseed dietary fibers lower cholesterol and increase fecal fat excretion, but magnitude of effect depend on food type. Nutr Metab (Lond) 2012;9:8

69 Thakur G, Mitra A, Pal K, Rousseau D. Effect of flaxseed gum on reduction of blood glucose and cholesterol in type 2 diabetic patients. Int J Food Sci Nutr 2009;60(Suppl 6):126-136

$70 \mathrm{Du} \mathrm{H}$, van der A DL, Boshuizen HC, et al. Dietary fiber and subsequent changes in body weight and waist circumference in European men and women. Am J Clin Nutr 2010;91(02):329-336 